\title{
Meeting the Refugee Challenge: The Dutch Experience
}

\author{
Loeky Droesen
}

\begin{abstract}
The Dutch asylum policy has been one of trial and error over the past four decades. This article will chronicle its most important twist and turns. It will do so by looking at the general premise of Dutch Alien law and by exploring the different residence statutes available to asylum seekers. Attention will be paid to the possibilities to appeal a decision, the investigation procedure and the Dutch reception model. Where relevant the upcoming amendments to the Dutch Alien Act are addressed as well.
\end{abstract}

\section{Résumé}

Aucoursdes quarantedernièresannées, la politique des Pays Bassurledroitd'asilea étécaractérisée pardestâtonnements. Cet article s'attache àraconter les plus importantes étapes dece parcourstouten virageseten retoursenarrière. Pourcefaine, il examinera les prémisses de la loi néerlandaisesurles Étrangers etexplorera lesdiversesloissurlanésidenceauxquelles les demandeurs d'asile peuventavoir recours. Uneattentionparticulièreseraportée aux possibilités de faire appel contre une décision, laprocédured'enquêteetlemodèle néerlandaisenmatièred'accueil. Làoù c'est applicable,lesamendementsannoncéspour bientôt à la loi néerlandaise sur les Étrangers (Dutch Alien Act), sont aussi examinés.

\section{Introduction}

Attending the Summer Course on Refugee Issues caused me to step back and reexamine my national system of refugee protection. One of the common threads running through the presentations was that everyone, confronted with the refugee problem, attempts to come up with some kind of solution. Often we had to

Loeky Droesen is a lecturer at the Institute of Higher European Studies (HEBO) and at the Master's of European Law and Policy (MAELP), Haagse Hogeschool (The Hague University of Professional Education), The Hague, The Netherlands. conclude that noperfect solution was in sight. In this paper I want to demonstrate that the Netherlands has also been on a continuing quest for the "perfect" solution of its refugee "problem" and has been unable to find it.

The Dutch quest for solutions has been a process of trial and error, with a few striking characteristics. First of all, new laws, regulations and policies are introduced at a staggering speed. Secondly each new rule seems to be accompanied by its own set of exceptions. Moreover theserules and exceptions are often, on the one hand, based on, and on the other hand, fine tuned in policy decisions by the Dutch Immigration and Naturalisation Service, IND $^{1}$ and by the judgements of the Dutch Aliens Chambers. In this paper I will only be able to point out some of the basic rules of the Dutch system and will therefore need to make simplifications. I will chronicle some of the more striking twists and turns of the Dutch refugee law and policy of the past four decades.

\section{(1) Dutch Migration Law; The Basic Premise}

The Netherlands is a small ${ }^{2}$ country on the North sea coast of west Europe. It is one of the most densely populated ${ }^{3}$ countries in the world; This fact is reflected in a standard phrase used in residence determination decisions. "The Netherlands is a densely populated country, because of the resulting problems in the population and employment situation, a restrictive migration policy is in place."4 The basic premise of the present Dutch migration policy is restrictive indeed. It states that no alien is allowed to reside in the Netherlands, unless an exception applies. The Aliens Act Implementation Guidelines ${ }^{5}$ formulates the three exceptions. Aliens are allowed residence in the Netherlands if; "their presence in the country serves an essential Dutch interest" ${ }^{\text {(e.g. ex- }}$ change students, au pairs, and athletes, e.g. exceptional soccer players). Furthermore aliens are allowed to stay if "there are reasons of a compelling humanitarian nature" 7 to allow residence (e.g. family reunification cases, people traumatised by experiences in their country of origin or people who do not meet the refugee definition but are deemed in need of protection none the less. (I will come back to these last two situations in paragraph 3) And the last exception to the non admittance rule is based on the Netherlands' international treaty obligations, (e.g. the European Union Treaties). An important Dutch international obligation was created by the signing and ratification of the 51 Geneva convention. ${ }^{8}$ It forms the basis of Dutch Refugee Law and Policy.

\section{(2) Dutch Refugee Law and Policy; An Introduction}

The Netherlands ratified the Geneva Convention on the third of May 1956. The Country was recovering from the post second war economic slump and immigration to the Netherlands was limited. In fact a considerable number of Dutch emigrated, many of them to Canada. In the first years after the ratification, the determination whether a person qualified as a convention refugee was left to the UNHCR. If the UNHCR representative declared a person a refugee under its mandate, the Dutch authorities would start the procedure to grant a residence permit ${ }^{9}$ Many of the refugees who were accepted into the country came from behind the Iron curtain (the communist countries) and received a warm welcome.

In 1965 a new Dutch Aliens Act was drafted. In Article 15.1, the main part of the Geneva Convention Refugee Definition was incorporated. Article 15.1 stated: "Aliens coming from a country where they have a well founded reason to fear persecution based on their religious or political opinion or nationality or based on their belonging to a certain 
race, or particular social group, can be granted admittance by the Minister.".A person accepted as a refugee under article 15.1 was granted the so-called Astatus, or admittance as a convention refugee ${ }^{10}$

In practise not much chanced. The Dutch authorities would not start an admittance procedure until the UNHCR had declared a person a refugee. The Netherlands was going through an economic boom and was actively seeking labour migrants in Italy, Spain, Portugal, Marocco and Turkey. The number of asylum seekers was low. In fact the State Secretary H. Grosheide, responsible for the Dutch Aliens Policy between 1970 and 1973 can only recall one asylum case which went to court, the case of an American Vietnam deserter ${ }^{11}$ Despite the low numbers (386 in 1975) ${ }^{12}$ in the middle seventies refugees and asylum seekers first becamea political issue in the Netherlands. The Dutch government was confronted with a number of asylum requests from young Portuguese men, refusing to be drafted into the military as a protest against their country's colonial war. Because it was politically inconvenient to accept draft dodgers from a friendly State, the Dutch government was reluctant to accept these people as convention refugees. ${ }^{13}$ The situation caused a strain in the relationship with the UNHCR, because the Netherlands was no longer willing to accept the UNHCR refugee determinations. In august 1975 the UNHCR decided to end refugee determinations in the Netherlands. ${ }^{14}$ The Dutch Ministry of Justice became the official body responsible for determining the refugee claims of asylum seekers. The situation of the Portuguese draft dodgers also led to the first introduction of, what became a recurring theme in the next three decades, a new protection status for people seeking asylum in the Netherlands.

\section{(3) Receiving Asylum in the Netherlands}

A number of the Portuguese cases were not accepted as convention refugees under article 15.1 of the Dutch Aliens Act, but were given the right to reside based on the fact that they were "asylum justified" 15 cases. This right to reside was commonly known as the B-status. The policy decision to create the new status, was in line with the general reluctance of the Dutch government to grant people the convention (A) status. ${ }^{16}$ The B status was given from 1974 onwards to people "who could not be expected to return to their country of origin due to the political situation." The determination to grant a B status was policy based and most Dutch writers agree that it never became altogether clear where the line was drawn between the A (Convention) status and the B status. ${ }^{17}$ Many asylum seekers appealed against the granting of a B status because they felt their experiences justified receiving the A status. This development resulted in an increase in asylum cases being brought before the Council of State. ${ }^{18}$ In 1988 the Council of State decided the B status would have to be abolished, because the Council could nolonger distinguish between the requirements to receive the $A$ status or the B status.

In the same time frame, the Dutch economy had taken a turn for the worst and unemployment was rising quite rapidly. The numbers of asylum seekers . was increasing as well. By 1985, 586519 people asked for asylum. Increasingly asylum seekers came to the Netherlands in larger groups. (eg Vietnamese boat people and Turkish Christians.)

In 1985 a large number of Tamil asylum seekers reached the Netherlands. The arrival of the Tamils is generally seen as a watershed in the Dutch public acceptance of asylum seekers. The conflict in Sri Lanka was unknown to the general public. The arrival of large groups of Tamils in chartered planes, led to a shift in the public debate. For the first time agroup of asylum seekers was identified as "economic fortune seekers", people who should not receive protection.

The eighties also saw the emergence of yet another status. This option became known as the $C$ status and was awarded by the Ministry of Justice based on it's powers to grant residence because of reasons of a compelling hu- manitarian nature. The criteria to be awarded a $C$ status have to be distilled from the various existing policies. A few groups can be identified; People who are traumatised by their experiences in the country of origin, people who because of ill health cannot return to their country of origin and those people who have been waiting for a decision on their request to be granted residence for over 3 years, have all be awarded the $C$ status. ${ }^{20}$ In comparison to the A status, C status holders have less rights to eg family reunification and work. In part because of this difference, many people who received a $C$ status continued their legal battle to receive the A status. This and the growing number of asylum seekers led to increasing pressure on the capabilities of the IND and the Dutch Courts.

In the beginning of the nineties, two more policy based, residence possibilities were created to be awarded to people asking for asylum: the gedoogden Status and the on theemden status. The gedoogden status was awarded to asylum seekers from Somalia, Ethiopia, Iran, and Iraq ${ }^{21}$ The ontheemden ${ }^{22}$ status was designed in 1992 to deal with the influx of people escaping the violence in the former Yugoslavia.All former Yugoslavs received the right to accommodation and some money but no option to receive a stronger residence status regardless of their personal circumstances.

The common link between these two options was that they were created to deal with specific influxes of asylum seekers. The Dutch policy makers created these possibilities because, they felt it would be inhumane to send these groups back to their country of origin. But policy makers also expressed great concern about the "magnetic appeal" ${ }^{23}$, that granting these groups strong residence rights, might have on the people remaining in their countries of origin. Therefore, the recipients of these residence permits received very limited rights. Policy makers and politicians also started to stress their desire to stem the "stream" of asylum seekers coming to the Netherlands. Granting limited residence rights was seen as a useful 
tool to deter "economic" refugees from trying to seek asylum in the Netherlands.

In order to avoid having to create additional incidental solutions for new influxes of asylum seekers, in 1994 the Dutch Aliens Act was amended (article $12 \mathrm{a}$ and $12 \mathrm{~b}$ ) to include a new residence status, the provisional residence permit (VVTV). ${ }^{24}$ The VVTV can beawarded by the Ministry of Justice in cases where "forced expulsion to the country of origin would result in exceptional hardship for the alien, given the overall situation there." 25 The Dutch government wanted to create the possibility to offer temporary protection to people fleeing eg civil war by granting them a VVTV status. To put a VVTV policy in place, the Dutch authorities assess the situation in a country in turmoil and all asylum seekers originating from this country will beawardedaVVTV. (VVTV policies have been in place for eg people coming from Angola, Iraq, the great lakes area in Africa and Bosnia) As soon as the situation in the country of origin improves, the recipients of the VVTV status are expected to return. The VVTV status has very limited rights attached to it. Because it was deemed inhumane to keep people in limbo about their future indefinitely, the VVTV status holder is allowed to apply for the strongerCstatusafterthreeyears. ${ }^{26}$ The high influx of asylum seekers, ${ }^{27}$ the increasingly complex system of status determinations, and the myriad of possibilities to appeal on aspects of the case led to long delays and backlogs in the determination system. Increasingly government communications about the asylum policy stressed the fact that there were limitations to Dutch hospitality. A brochure entitled "the Aliens policy knows its limits" ${ }^{28}$ describes the basis of the Dutch policy as follows: "The alien's policy is just but severe and the reception facilities are humane but sober."..."Real refugees have to be able to find shelter in the Netherlands. To be able to offer these people protection it is necessary to make a strict selection."

Many of the Dutch policy measures in the nineties were geared at trying to diminish the influx of people, to relief the pressure on the determination system. Examples of measures include: excluding manifestly ill-founded and inadmissible ${ }^{29}$ cases within 24 hours (now expanded to 48 hours), introducing carriers sanctions, making Dublin claims $^{30}$ and the adoption of a bill on undocumented asylum seekers. An asylum seeker entering the Netherlands without documents is presumed to have an ill-founded claim, unless he/she can produce a strong reason explaining the lack of documentation. The UNHCR has expressed its concern about this measure ${ }^{31}$ which does not take into account the reality of people in flight.

But these measures were not sufficient to end the above mentioned problems, so in the new millennium the Netherlands started a far reaching overhaul of its asylum determination system. A Dutch Aliens Act has been accepted by the Dutch parliament on 14 June 2000 and the Dutch government is aiming to have the new system in place by the first of July 2001. ${ }^{32}$ (This despite concerns expressed by the Courts, IND and the reception agency, that they may not be ready to implement the new law on time).

Under the New rules, asylum seekers are still eligible for a residence permit on the basis of the three possiblities explained above. (The Netherlands' International obligations including the Geneva Convention; for urgent reasons of a humanitarian nature or on the grounds that return to the country of origin would involve exceptional hardship). Once accepted however, each asylum seeker will receive the same temporary residence permit. The temporary permit will confer a given set of rights and benefits. After three years the recipients of the temporary permit will be eligible to receive a residence permit for an indefinite term. ${ }^{33}$

Whereas before the uncertainty of living with a temporary status for three years was only part of the life of the VVTV status holders, it will now become the fate of all accepted asylum seekers in the Netherlands. It is interesting to note that the term of three years was first introduced in policy and jurisprudence to end the uncertainty of a specific group of asylum seekers. Those asylum seekers who had been waiting for three years, and had not received a decision on their request for admission, where given a residence status on humanitarian grounds. It was deemed inhumane to keep them waiting any longer. ${ }^{34}$

The present system with three statuses conferring entitlement to different sets of rights and benefits often led to litigation, because recipients of the weaker entitlements attempted to obtain a stronger set of entitlements. One of the goals of the new system is to limit litigation in asylum cases. Limiting appeal possibilities has been a recurring theme in Dutch asylum policy as the next paragraph will show.

\section{(4) Appeals in the Dutch Asylum Policy}

Because the decision to grant a residence permit was part of the powers of the state, the judicial possibilities of an asylum seeker to appeal against a decision, were governed by the rules of Dutch Administrative law. If the Ministry of Justice took a negative decision on an asylum application, the asylum seeker could file an objection with the administrative authority. The executive would have to review the case and take a new decision. If this second decision was negative again, the asylum seeker could file an appeal with the Council of State.

In the beginning of the nineties the number of appeals had grown to a level which the Council of State was illequipped to deal with. A major overhaul of the general Dutch Administrative law was taking place, which led to a change in the Dutch Aliens Act on the first of January 1994. But instead of bringing the Aliens Act in line with the general principles of Dutch administrative Law ${ }^{35}$, the changes in the Dutch Aliens Act created exceptions to these general principles.

One implemented difference was the shorting of the term within which the asylum seeker can file an objection. Whereas under general Dutch Administrative law a person has 6 weeks to file an objection, the alien has 4 weeks. And although the executive has eight weeks 
to decide on an objection in allnon Alien Law cases, this period was extended to 6 months in the Aliens Act (art 15 e) for all Alien cases. Thenew Aliens Act, to be implemented in July 2001, take this difference one step further. The six month period can be extended by ministerial order with a year (i.e. a total of 1.5 years) for certain categories of aliens. TheMinister can decide to use this option if the situation in the country of origin is expected to remain uncertain for a short period, is expected to improve in the near future or if the number of applications is so large that the IND cannot process them within the six month period. Considering that the IND has been having considerable problems to meet the 6 month deadline, it is quite likely that under the new system, a considerable number of asylum seekers will not be able to obtain a permanent residence permit until they have remained in the Netherlands for 5.5 years ( 1.5 plus 3 years temporary permit).

But the most important difference implemented in January 1994 created a real uproar among legal scholars and refugee advocates in the Netherlands. ${ }^{36}$ The government decided to abolish the right to appeal to the Council of State in all alien cases, thereby creating an inequality in the legal protection offered to Dutch national and non-Dutch nationals, in the name of expediency.

A special Court was installed to deal with all Alien Law cases, the Alien Court in The Hague, which has mandated sessions to other courts in the country. ${ }^{37}$ The The Hague Court realised early on that without an Appeal Court and with 5 Aliens Courts deciding cases, it was necessary to create a way to maintain legal unity. The judges working in the different Aliens Courts, convened the so called Chamber of Standardisation. ${ }^{38}$ In this Chamber several of the Alien Law judges come together to take decisions in cases which deal with the more complicated or contentious legal or policy questions. (For instance on 27 August 1998 the Chamber ruled that persons persecuted by non-State agents may fall within the ambit of the Geneva Convention. ${ }^{39}$ The Chamber has no official standing under the Law and the value of its judgements is based on the agreement among the Alien judges that they will follow the jurisprudence of the Chamber.

Almost as soon as they were established the Aliens Courts were hard pressed to deal with all the cases that were brought before them. Besides cases about the validity of the asylum claim, a number of other issues were dealt with by the Courts. An asylum seeker whose first application had been denied, was in most cases, not allowed to remain in the Netherlands to await the outcome of the objection phase. Many asylum seekers would file a motion to begranted leave to stay, pending the decision to the objection.Moreover the IND was increasingly having trouble meeting the six month deadline, leading to the legal assumption that the executive had refused to take a decision and opening the possibility to appeal to the Court. Court cases also dealt with questions of termination of reception facilities, eviction from accommodation and expulsion orders.

In 2001, seven years after its abolition, the Council of State will now be reintroduced as an Appeal Court in Dutch Alien Law cases. In hopes of diminishing the time involved in the decision making process, the Dutch authorities have now decided to abolish another part of the appeals phase. Asylum seekers will nolonger be able to lodge an objection to the executive who has rendered a negative decision on their application. The objection procedure will be abolished in Alien cases. Instead the asylum seeker will make an appeal to the Court.

To decrease the volume of cases, it has been decided that all asylum seekers are allowed to remain in the Netherlands pending their appeal to the Court. It will no longer be necessary to file a separate case to ask for a leave to stay. Moreover, the rejection of the application by the Court will automatically lead to the obligation to leave the Netherlands and will terminate the right to reception facilities. The asylum seeker will no longer be able to file separate appeals related to these issues.

Despite expectations that these new rules will diminish some of the case load, the new role of the Courts will undoubtedly lead to more work. Therefore the Dutch authorities have decided to greatly expand the number (from 6 to 21) of Alien Courts. ${ }^{40}$

Although the IND should have a diminishing case load with the disappearance of the objection phase, the Dutch government has chosen to expand its workforce. This is necessary to try to process all of the currently pending cases as soon as possible. But it is also part of the continuing attempts to improve the quality of the work of the IND. "The abolition of the objection phase means that the quality of the initial decision of the IND has to be improved. The Dutch authorities hope to achieve this by enabling the asylum seeker to explain clearly their motives for requesting asylum and, where it is proposed to refuse their application, by asking them for their reaction to such a decision. In its final decision on the request for admission the IND is to take account of how both the IND and the alien view the application. This will provide a sufficient basis for a review by the Courts of whether the decision has been taken legally." 41

\section{(5) Establishing Asylum Motives The Dutch Way}

How do the Dutch authorities enable an asylum seeker to explain clearly their motives for requesting asylum? In the system in place today a person who asks for asylum is brought to one of three Application centres. ${ }^{42}$ Within 48 hours the authorities will determine, on the basis of a short interview, whether a person's claim is valid. Those cases which are deemed manifestly illfounded or inadmissible, will not be allowed to continue. About three quarters of the people asking for asylum go to go the next phase and are transferred to an Investigation and Reception centre. ${ }^{43}$

In the Investigation and Reception centre, the asylum seeker will be interviewed about the asylum motives by a contact officer. ${ }^{44}$ One can detect many imperfections in this system. Often the 
asylum seeker is tired, traumatised, distrustful of authorities and not aware of the extreme importance of this one interview in the determination of the asylum claim. The contact officer has limited time to find out relevant information with the aid of an interpreter, which makes communication difficult. The contact officer has to try to be compassionate but at the same time has to establish the trustworthiness of a claim and the claimant. Especially in the beginning of the nineties, the quality of the contact officers skills left much to be desired. At the time it was not uncommon for people to be hired as contact officers' by temporary workagencies. In the past several years training in multicultural communication and the specific problems of torture and rape victims has been introduced.

The contact officer will write a report on the basis of the interview. This is in no way a verbatim report of the interview, but a summary of the questions and answers. The quality and thoroughness of the contact officer's report are essential in a person's asylum claim. The Report is in general seen as the gospel truth. Any additions, improvements or changes to the story madeby the claimant after the interview are treated at best as less relevant and at worst as proof of the person's unreliability by the IND and the Courts. ${ }^{45}$

The Report is send on to the determination officer ${ }^{46}$ Based on the content of the report and the available information about the country of origin, the determination officer will decide if a person will receive a residence status or not. The determination officer does not meet the asylum seeker, unless a second hearing is called for in the objection phase.

The Dutch asylum procedure has increasingly become adversarial. On the one side you find the asylum seeker and their lawyer trying to prove the validity of the claim and on the other side the IND trying to discredit the claim. One writer has even gone so far as to characterise the relation as a guerrilla warfare. ${ }^{47}$ In 1990 Amnesty International published a book called the drawback of the doubt ${ }^{48}$, highlighting the many instances in the Dutch procedure in which the asylum seeker was not given the benefit of the doubt but rather the reverse. In case of doubt the person is not deemed to be credible. In one case, I saw the life experience of a man from Zaire (who had been imprisoned, tortured and whose wife had been raped in front of him) narrowed down to a question about one of the 10 documents he brought to prove his identity. Because one number in a date on a driver license had been changed from a one to a two, the IND ruled his whole story was not credible. In the last years a few experiments have started toattempt to return to a morecooperative, inclusive, and less adversarial approach.

\section{(6) The Reception of Asylum Seekers $^{49}$}

Over the last few decades the Netherlands has developed an extensive reception programme. Until the beginning of the eighties the Dutch government was not involved in the reception of asylum seekers. Asylum seekers who arrived in the Netherlands received a payment based on the Law ${ }^{50}$ which grants financial assistance to inhabitants of the Netherlands who have an income below the statutory minimum. The asylum seeker could find their own accommodation or ask the municipality to assist them in finding a place. It is important to note that in the densely populated Netherlands, there is a consistent shortage of housing available, in particular in the low rent categories.

When the large groups of Tamils arrived in 1985, the Netherlands faced its first reception crisis. (see also paragraph 3) . The Municipalities where most of these Tamils tried to find accommodation, found themselves unable to help. The national government stepped in and set up reception centres for the first time.

\section{Endnotes}

1.Immigratie en Naturalisatie Dienst. The IND is a part of the Dutch Department of Justice and responsible for the determination of asylum claims in the Netherlands. I have chosen to use the English translation for specific Dutch terms in the text. The footnote will give the original Dutch term. The translations were taken from Begrippenlijst Vreemdelingenrecht, IND, maart 1996. 2. Total area of the Netherlands 41,000 sq $\mathrm{km}$ or $16,000 \mathrm{sq} \mathrm{mi}$. To contrast Canada's area is $9,970,000 \mathrm{sq} \mathrm{km}$ or $3,849,000$ sq mi.

3. Population of the Netherlands is approximately 16 million. To contrast Canada's population is approximately 30 million.

4.A liberal translation of "Nederland is een dichtbevolkt land en in verband met de daaruit voortvloeiende problemen, zoals gelegen in de bevolkings- en werkgelegenheidssituatie, wordt een restrictief toelating beleid gevoerd."

5.Vreemdelingencirculaire.

6. liberal translation of "indien met hun aanwezigheid een wezenlijkNederlands belang wordt gediend." 7.liberal translation of "indien er sprake is vanklemmende redenen van humanitaire aard."8.Convention relating to the status of refugees of 28 July 1951.

9. "Door het oog van de naald, een commentaar op de praktijk van de asiel procedure", .Domenica Ghidei Biidu, ISIS, Utrecht, 1995, pg 43-45.

10.It is impossible to address in this paper the legal consequences of the differences between the Dutch and Geneva Convention definition; see e.g. "Vluchtelingenrecht", T.P.Spijkerboer en B.P. Vermeulen, Amsterdam, 1995, p. 212 - 218.

11. "Van een Vietnam-deserteur tot duizenden Kosovaren", Micha Kat in Intermediair, 13 mei 1999, 35 jaargang, nummer 19.

12. number given by the State Secretary of Justice Cohen in a speech on 6 april 2000 , http://www.minjust.nl/c actual/ speeches/sp0078.htm.

13. "Vreemdelingenrecht; toelatingen verblijf van vreemdelingen in Nederland", Th. Holterman, W.E.J Tjeenk Willink, Deventer, 1999, pg198 - 201.

14.Biidu, Supra note IX, p. 43-45.

15. asielgerechtigd.

16. "Inleiding in het Migratierecht", P. Boeles, Amsterdam, 1992, pg 104 - 107.

17. Ibid p. 104 - 107 and Spijkerboer, Supra note XI, p. 310 - 313 .

18. Raad van State, the Dutch Administrative High Court. 
19. number given by the State Secretary of Justice Cohen in a speech on 6 April 2000 , http://www.minjust.nl/c actual/ speeches/sp0078.htm.

20. Spijkerboer, Supra note XI, p. 313 - 322.

21. gedoogden is a typically Dutch term which is very hard to translate. It means that the people were not residing in the Netherlands legally, but were allowed to remain under certain conditions laid down in policy regulations. ( The famous Dutch drugs policy is based on the same principle, selling marihuana is not legal in the Netherlands but it is gedoogd/allowed, if the shop complies with certain policy regulations.).

22. ontheemden (another hard to translate term) This status was designed in 1992 to deal with the influx of people escaping the violence in the former Yugoslavia. All former Yugoslavs received the right to accommodation and some money but no option to receive a stronger residence status regardless of their personal circumstances.

23.Aanzuigende werking, literal translation suction working.

24. Voorwaardelijke Vergunning tot Verblijf

25. liberal translation of "gedwongen verwijdering naar het land van herkomst van bijzondere hardheid voor de vreemdeling zou zijn in verband met de algehele situatie aldaar."

26. Spijkerboer, Supra note XI, p. 327-330 and Holterman, Supra note XIV, p. 180 - 181.

27 . some numbers influx in $1992 ; 20,346$, in $1996 ; 22,857$, in $1998 ; 45,217$ and in 1999 (numbers till September 1999) 27,598. Canada's influx in 1992; 37.748, in 1996 25.633 , in $1998 ; 24.937$, and in 1999 (numbers till august 1999) 17.393, Http:// www.igc.ch/1999.htm.

28.a brochure published by Dutch Immigration and Naturalisation service in 1996 in inform the general public about the aliens policy.

29. kenelijk ongegrond en niet ontvankelijk.

30. The Dublin convention sets up a system among its signatories to determine which country is responsible to determine an asylum seekers claim. A Dublin claim is made to the Dublin convention signatory state which the Netherlands deems responsible to hear a person asylum claim because the person travelled through this country to enter the Netherlands.

31.http://www.unhcr.ch/world/euro/ nthrlnds.htm.

32. "geen uitstel Vreemdelingenwet 2001"; gids vreemdelingenrecht, nieuws, april 2000, Kluwer afl.

33.http://www.minjust.nl:8080/a_beleid/ fact/aliens.htm.
34.Spijkerboer, Supra note XI, p. 316 - 317.

35. laid down in the General Law Administrative law (Algemene Wet Bestuursrecht) of 1 January 1994.

36. see e.g. Spijkerboer, Supra note XI, p. 335 -341 and $379-387$.

37. The Courts in Amsterdam, Haarlem, Haarlemmermeer, Den Bosch and Zwolle were called upon to act as so called additional session courts (nevezittingsplaatsen).

38.Rechtseenheidkamer.

39.Holterman, Supra note XIV, p. 190.

40. "Tweede kamer akkoord met uitbreiding aantal nevenzittingsplaatsen", gids vreemdelingenrecht, nieuws, mei 2000 , Kluwer afl.11.

41. http://www.minjust.nl:8080/a_beleid/ fact/aliens.htm.

42. Aanmeld centrum. There are application centres in Rijsbergen, Zevenaar and Schiphol.

43. Onderzoeks en opvangcentrum.

44. contact ambtenaar.

45. Spijkerboer, Supra note XI, p. 350 - 354 .

46. beslis ambtenaar.

47. Holterman, Supra note XIV, p. 78 - 81.48. "Het nadeel van de twijfel, de rol van informatie in de Nederlandse asiel procedure" Amnesty International, 1990, Amsterdam.

49. Most of the information used in this paragraph is drawn from the excellent student paper "The reception of asylum seekers in the Netherlands", Astrid Arends, Institute of Higher European Studies, May 2000. (copy available in Haagse Hogeschool library or from writer of this article).

50. Algemene Bijstandswet, the General Assistance Law.ם

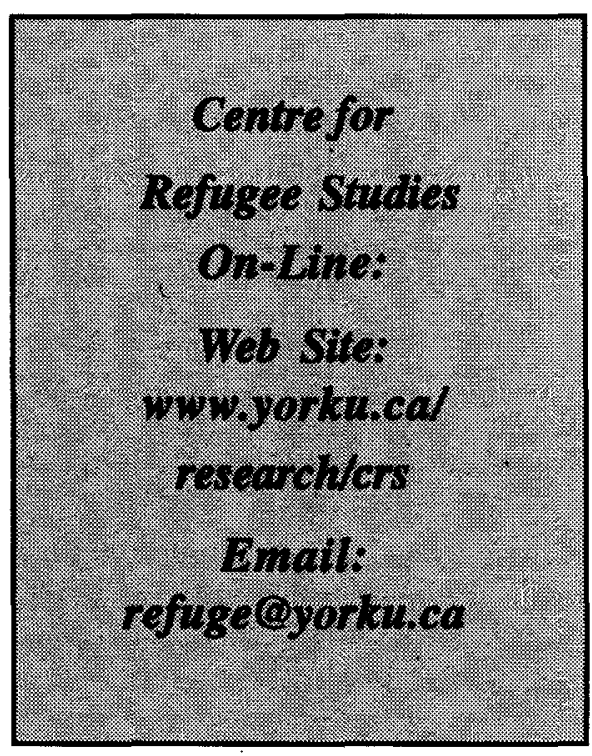

\section{Paths to EQUTY:}

\section{Cultural, Linguistic, and Racial Diversity in Canadian Early Childhood Education}

\section{By Jwdith K. Benlhard, Morie Lowise Lffebres Gyds Choh. and Rike Lang:}

Toronto: YorkLanes PressiSBNI.

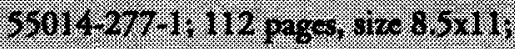

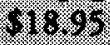

Paths to Equirgy is based on an exten-

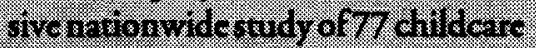
centres is Mornered, Toronto, and Vancouver on the culturi, Inguistic, and racial diversity in Canadian Eaty Chillhood Education (ECE). The epport presents die resulks this study on how the ECE gytem is responding to the incressing divert sigy of contemporery Canadian soct: cty.

la dhis ground breakingstudy, the athors have addressed teachers? tiens on divarity in dhe education progransiparenus difficulities in colt laborating within dic current educa. tion syrem; resehers' difficulties in underseanding nany "cehmic' part ents: decirc of many parenss for berter communicacion with staff: preferebly in thicir own languages. and for more informationabout their individual children, and chances for effective inpute and the cridence of somic continuing problterns with rec. ism, inreppective of the good intent tions of enated itif:

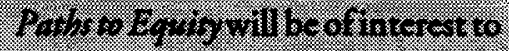
RCE faculy, poligymakes, centre supervisors and staff and others interested in the anclustion of diversity content in professional calucation progranis:

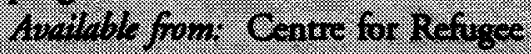
Studies, Fase (416) 73658837 